\title{
CONTRIBUTION TO THE STUDY ON TRICULINAE SNAIL GROUP (POMATIOPSIDAE - MOLLUSCA) IN TAY NGUYEN HIGHLAND, VIETNAM
}

\author{
HO THANH HAI, DANG NGOC THANH
}

\author{
Institute of Ecology and Bioresources
}

\begin{abstract}
Based on taxonomical analysis of snails collected from streams belonging to Srepok River, two new species belonging to genus Pseudotricula Dang et Ho, 2006 are recorded. These snails can be representative populations of subfamily Triculinae - Pomatiopsidae existing in Tay Nguyen Highland, central Vietnam that located in watershed area of Mekong river system.
\end{abstract}

Genus Pseudotricula Dang et Ho, 2006 was established based on type species Pseudotricula undulata Dang et Ho, 2006. Up to now, the new genus Pseudotricula Dang et Ho seems to be characterized for small streams in mountainous area, having 9 species, including these two new species.

In 1992, Ponder W. F. (1992) has established genus Pseudotricula Ponder, 1992 with type species Pseudotricula eberhardi Ponder n. sp., found in a cave stream at Tasmania (Australia). According to the shell description given by this author [14], the genus Pseudotricula Ponder seems to be clearly different from the genus Pseudotricula Dang et Ho, 2006. By shell structure, as well as, by cave living conditions of Pseudotricula eberhardi Ponder, 1992, the type species of this genus (in type locality at Tasmania, Australia). However, conforming to the International Code of Zoological Nomenclature (ICZN), Pseudotricula Dang et Ho, 2006 must be considered as a junior homonym of the genus Pseudotricula Ponder, 1992. Therefore, by ICZN, the generic name of Pseudotricula Dang et Ho, 2006 must be eliminated and replaced by the new name Vietricula Dang et Ho, 2008, proposed by the authors. Hence, Pseudotricula undulata Dang et Ho, 2006 - type species of the genus Pseudotricula Dang et Ho that to be considered as the type species of the genus Vietricula Dang et Ho, 2008 (ICZN, 2000, Articles 678, 727).

Based on analysis of snail specimens, two new species Vietricula serepoki Dang et Ho sp. n. and V. laki Dang et Ho sp. n. are also described in this paper.

Keywords: Triculinae snail, Tricula, Pseudotricula, Pseudotricula eberhardi, Pseudotricula undulata, Vietricula, Vietricula undulata, Tay Nguyen Highland

Among freshwater snail samples collected from streams belonging to Srepok river, Dak Lak province, Tay Nguyen Highland - Vietnam, many specimens belonging to triculine groupPotamiopsidae. The result of taxonomical analysis shows that these snails are two new species belonging to genus Pseudotricula Dang et Ho, 2006 but clearly differ from all known species of Triculinae's group found in streams of the northwestern area of Vietnam. These snails can be representative local populations of Triculinae existing in the Taynguyen Highland central Vietnam, that located in watershed area of Mekong river system.

Genus Pseudotricula Dang et Ho, 2006 was established based on the new species Pseudotricula undulata Dang et Ho, 2006 with the following generic diagnosis: shell small, with 5-6 whorls, body whorl equal or longer than spire length, rather inflated and aperture variable, from semi-lunar to water-drop in shape, lip single or double. Up to now, the new genus Pseudotricula seems to be representative by 7 species characterized for mountainous streams found in northwestern area of Vietnam [5] and 2 new species recently found in Tay Nguyen Highland.

As we know, in 1992, Ponder W. F. has established the genus Pseudotricula Ponder, 1992 based on the typ species Pseudotricula eberhardi Ponder,1992 found in cave stream at Tasmania, Australia (Ponder, W. F., 1992). According to the shell description given by this author, Pseudotricula Ponder is clearly differed 
from genus Pseudotricula Dang et Ho, 2006 by the following characteristics: Shell short, broadly conical in shape, spire length very shorter than body whorl; aperture large, nearly round, with thickened, reflected outer lip. In addition, Pseudotricula eberhardi Ponder, type species of Pseudotricula Ponder seems to be characterized by the cave living conditions in dark zone of caves at Tasmania (Australia), strictly different from the normal living conditions in mountainous stream in Tay Nguyen Highland, Vietnam of Pseudotricula undulata Dang et Ho, type species of genus Pseudotricula Dang et Ho, 2006. Therefore, Pseudotricula Dang et Ho must to be a taxon different from the above mentioned genus Pseudotricula Ponder. However, the name of the genus Pseudotricula Dang et Ho published later in 2006 must be considered as an junior homonym of Pseudotricula Ponder, 1992 .Conforming to the International Code of Zoological Nomenclature (ICZN), the name Pseudotricula Dang et Ho must be eliminated and replaced by the new generic name Vietricula Dang et Ho, 2008 proposed by the authors. Pseudotricula undulata Dang et Ho, 2006 - type species of the genus Pseudotricula Dang et Ho that to be considered as the type species of genus with new nomination
Vietricula Dang et Ho, 2008 (ICZN, 2000, Articles 678,727$)$. The following are diagnosis and descriptions of the new genus and two new species belonging to subfamily Triculinae:

\section{Vietricula Dang et Ho nom. nov.}

Pseudotricula Dang et Ho, 2006 (non Ponder, 1992)

Diagnosis: Shell small, long-pyramidal in shape, inflated, smooth., with 5-6 whorls. Body whorl equal or longer than spire height, aperture variable, from semi-lunar to water-drop in shape, lip single or double. Peristome without reflected outer lip.

Type species: Pseudotricula undulata Dang et Ho, 2006.

\section{Vietricula serepoki Dang et Ho sp. nov.} (fig. 1)

Holotype: length $7.0 \mathrm{~mm}$, breadth $3.2 \mathrm{~mm}$, length of aperture $3.5 \mathrm{~mm}$, breadth of aperture 2 $\mathrm{mm}$, collected from stream belonging to Srepok River at Dak Lak province. Paratype: 20 shells, deposited in IEBR, Hanoi, Vietnam.

Diagnosis: Shell small, pyramidal in shape, aperture narrow, semil-lunar in shape,acute angularly produced upper. Peristome thin, lip produced ahead.

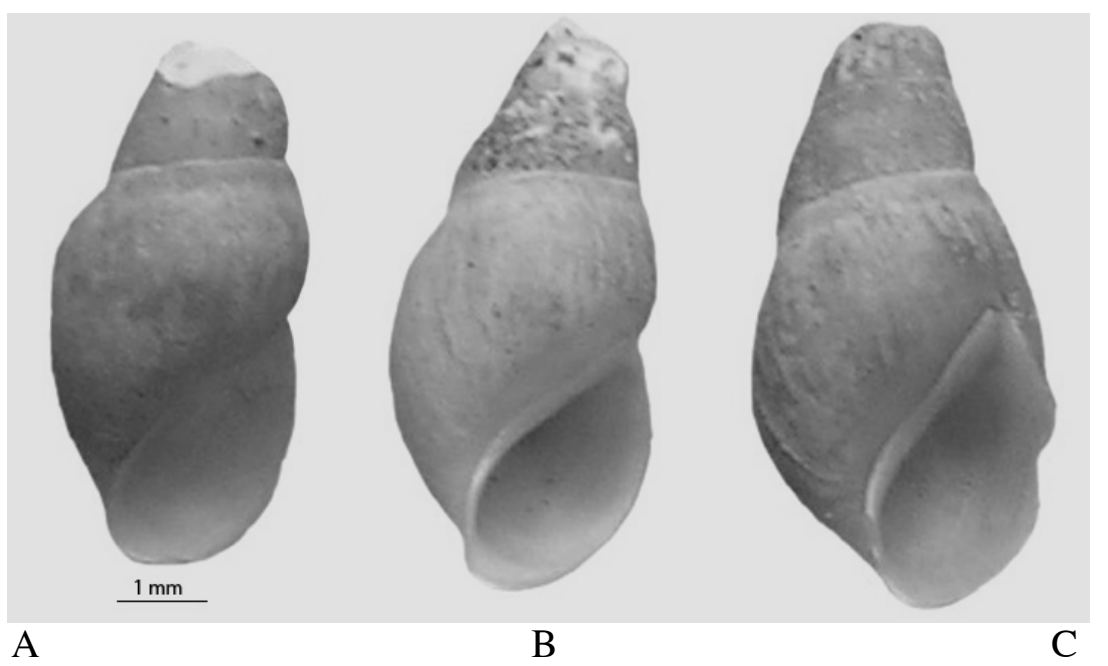

Fig. 1. Vietricula serepoki Dang et Ho sp.n. (B: holotype; A, C paratype)

Description: Shell small. Pyramidal in shape, length $7 \mathrm{~mm}$. Spire apex eroded. Shell smooth, axial/vertical furrowing thin, opaque in body whorl. Whorls 5, body whorl inflated, breadth 3-4 mm, body whorl longer than spire length, equal 0.64-0.71 length of shell. Suture 
shallow, single in young specimens, double in mature specimens. Shell solid, colour of shell changed from brown-yellow to brown. Aperture narrow, moderately long,semi-lunar in shape, acute angle produced upper and below. Upper angle of aperture located in about middle part of the body whorl. Peristome thin, lip produced ahead. Callus thin and continuous. Umblicus unclear. Operculum unknown.

Size: h: 4-7; 1: 2,7-3,5; Lo: 2,5-3,5; lo: 1,12,0 .

Note: The new species Vietricula serepoki sp. nov. learly differs from the other known species of this genus by the aperture narrow, moderately long, acute angle produced upper and below.

Etymology: the new species is named wing tothe name of Srepok River.

Vietricula laki Dang et Ho sp. nov. (fig. 2)

Holotype: Length $7 \mathrm{~mm}$, breadth $4.0 \mathrm{~mm}$, length of aperture $3.8 \mathrm{~mm}$, breadth of aperture $2.8 \mathrm{~mm}$, collected from stream belonging to Srepok River at Dak Lak province. Paratype: 1 shell, deposited in IEBR, Hanoi, Vietnam.

Diagnosis: Shell small, long-conical in shape, aperture water-drop in shape, peristome thickened in ahead.

Description: Shell small, long-conical in shape, length $7 \mathrm{~mm}$. Apex eroded. Shell smooth, some areas eroded, axial/vertical furrowings thin, opaque in body whorl. Whorls 5 , body whorl moderately inflated, breadth $3.8-4.0 \mathrm{~mm}$, length of body whorl $5.0 \mathrm{~mm}$, longer than spire length, equal 0.71 length of shell. Suture shallow double in mature specimen. Shell solid, colour of shell changed from brown-yellow to deep brown. Aperture water-drop in shape, acute angle produced upper, round below. Upper angle located in about $2 / 3$ of the body whorl. Perostome thickened in ahead. Callus thick and continuous. Umbilicus unclear. Operculum unknown.

Size: h: 6.5-7; 1: 3.8-4.0; Lo: 3.1-3.5; lo: 2.7-2.8.

Notes: The new species Vietricula serepoki sp. nov. clearly differs from the other species of this genus in aperture water-drop in shape, peristome thickened in ahead.

Etymology: the new species is named owing to the name of Dak Lak province, Tay Nguyen highland.

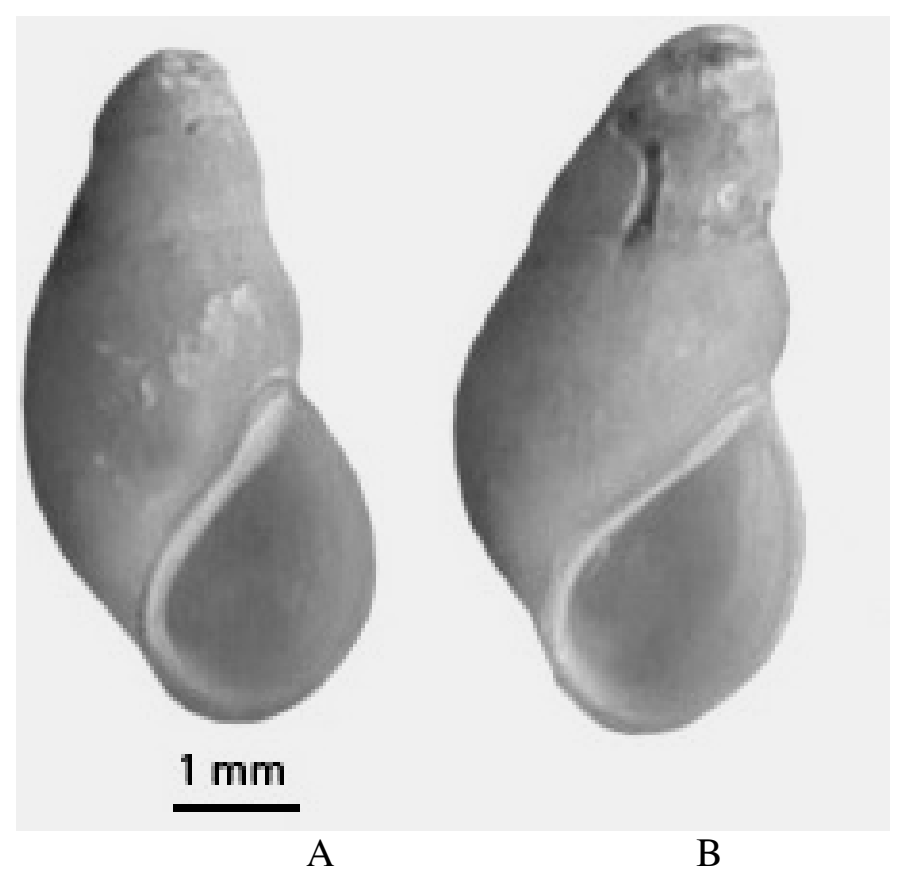

Fig. 2. Vietricula laki Dang et Ho sp.n. (B. holotype; A. paratype) 


\section{REFERENCES}

1. Abbott R. T., 1948: Handbook on the important mollusks of the Orient and Western Pacific. Bull. Mus. Comp. ZoologyHarvard College, 100(3).

2. Annandale N., 1924: Amer. J. Hyg. Monog., 33: 269-294.

3. Bavay et Dautzenberg, 1912: J. Conchyo., 60: 1-54.

4. Brandt R. A. M., 1974: The non-marine aquatic Mollusca of Thailand. Frankfurt am Main, 423 pages.

5. Dang Ngoc Thanh, Ho Thanh Hai, 2006: Journal of Biology, 28(1): 8-18. Vietnam.

6. Davis G. M., 1968: Malacologia, 7(1): $17-70$.

7. Davis G. M., 1979: The origin and evolution of the gastropod family Pomatiopsidae, with emphasis on the Mekong river Triculinae. Academy of Natural Scie. of Philadelphia, Monograph 20.

8. Davis G. M., Chen C. E., Kang Z. B., Liu Y. Y., 1994: Biomed. Environ. Sci.,
7(4): 369-382.

9. Davis G. M., 2003: J. Moll. Stud., 69: 263-271.

10. Liu Y. Y., 1974: Act. Zool. Sinica, 20(3): 223-230.

11. Liu Y. Y. et al., 1979: Mollusca in China (in Chinese).

12. Liu Y. Y. et al. 1983: Act. Zootax. Sinica, 8(2): $135-140$.

13. Liu Y. Y. et al., 1991: Act. Zootax. Sinica, 16(1): 1-16.

14. Ponder W. F., 1992: A new genus and species of aquatic cave-living snail from Tassmania (Mollusca: Gastropoda: Hydrobiidae). Papers and Proceeding of the Royal Society of Tasmania, 126: 23-28.

15. Prashad B., 1924: Rec. Indian Mus., 22: 67-69.

16. Rao H. S., 1928: Rec. Indian Mus., 30: 399468.

17. Yen T. C., 1939: Abbh. Senc. Naturf. Ges., 444: 1-234.

18. Wagner E. D. and Chi W. L., 1959: Amer. Jour. Trop. Med. Hyg., 8(2): 195-198.

\title{
GÓP PHẦN NGHIÊN CỨU NHÓM ỐC TRICULINAE (POMATIOPSIDAE - MOLLUSCA) Ở TÂY NGUYÊN, VIÊTT NAM
}

\author{
HỒ THANH HẢI, ĐẶNG NGOC THANH
}

\section{TÓM TÁT}

Trong số vật mẫu ốc thu được ở các suối nhánh thuộc sông Srê Pok, tỉnh Đăk Lăk, Tây Nguyên, có nhiều mẫu vật thuộc nhóm ốc Triculinae, họ Pomatiopsidae. Qua kết quả phân tích phân loại học, có hai loài mới thuộc giống Pseudotricula Dang et Ho, 2006 được xác định. Hai loài mới này khác rõ் rệt với các loài thuộc nhóm ốc Triculinae, đã thấy ở vùng núi Tây bắc. Có thể đây là những quần thể địa phương của nhóm ốc Triculinae ở Tây Nguyên, lưu vực sông Mê Kông.

Giồng Pseudotricula Dang et Ho, 2006 được xác lập trên cơ sở loài mới Pseudotricula undulata Dang et Ho, 2006 [5]. Trước đó, trên cơ sở các mẫu vật thu được trong suối hang ngầm ở Tasmania (Australia), năm 1992, Ponder W. F. đã xác lập giống mới Pseudotricula Ponder, 1992. Tuy nhiên, theo công bố của tác giả này [14], có thể thấy giống Pseudotricula Ponder, 1992 hoàn toàn khác với giống Pseudotricula Dang et Ho, 2006 ở chỗ: vỏ ốc ngắn, hình côn rộng, tháp ốc ngắn hơn nhiều so với vòng xoắn cuối, lỗ miệng rộng, gần tròn, vành miệng dày lộn ra ngoài thành môi ngoài. Hơn nữa, loài Pseudotricula eberhardi Ponder n. sp. tìm thấy ở suối ngầm trong hang ở vùng Tasmania (Úc), hoàn toàn khác với điều kiện sống trong môi trường suối tự nhiên của các loài đã biết thuộc giống Pseudotricula Dang et Ho ở Việt Nam. Tìm thấy gần đây ở các suối 
vùng núi phía bắc và Tây Nguyên Việt Nam. Vì vậy, giống Pseudotricula Dang et Ho phải được coi là một taxon hoàn toàn khác với giống Pseudotricula Ponder, 1992 nói trên. Tuy nhiên, theo Luật Danh pháp động vật (ICZN), tên Pseudotricula Dang et Ho, công bố năm 2006, phải coi là tên đồng danh mới của Pseudotricula Ponder, công bố năm 1992. Như vậy, tên giống Pseudotricula Dang et Ho, 2006 phải được loại bỏ và thay thế bằng tên mới Vietricula Dang et $\mathrm{Ho}, 2008$ do các tác giả đề nghị. Loài Pseudotricula undulata Dang et Ho, 2006 - loài chuẩn của giống Pseudotricula Dang et Ho vẫn được coi như loài chuẩn của giống với tên thay thế mới Vietricula Dang et Ho, 2008 (theo Luật danh pháp, các điều khoản 678, 727).

Trên cơ sở các vật mẫu thu được ở suối thuộc sông Srê Pôk, Đăk Lăk, Tây Nguyên, hai loài ốc mới Vietricula serepoki Dang et Ho sp. n. và V. laki Dang et Ho sp. n. được mô tả chi tiết trong bài này.

Ngày nhận bài: 21-10-2009 